\title{
Is callose a barrier for lead ions entering Lemna minor $\mathrm{L}$. root cells?
}

\author{
Sławomir Samardakiewicz • Magdalena Krzesłowska • \\ Henryk Bilski • Rafal Bartosiewicz • Adam Woźny
}

Received: 14 February 2011 / Accepted: 5 May 2011 / Published online: 18 May 2011

(C) The Author(s) 2011. This article is published with open access at Springerlink.com

\begin{abstract}
Plants have developed a range of strategies for resisting environmental stresses. One of the most common is the synthesis and deposition of callose, which functions as a barrier against stress factor penetration. The aim of our study was to examine whether callose forms an efficient barrier against $\mathrm{Pb}$ penetration in the roots of Lemna minor L. exposed to this metal. The obtained results showed that $\mathrm{Pb}$ induced callose synthesis in L. minor roots, but it was not deposited regularly in all tissues and cells. Callose occurred mainly in the protoderm and in the centre of the root tip (procambial central cylinder). Moreover, continuous callose bands, which could form an efficient barrier for $\mathrm{Pb}$ penetration, were formed only in the newly formed and anticlinal cell walls $(\mathrm{CWs})$; while in other $\mathrm{CWs}$, callose formed only small clusters or incomplete bands. Such an arrangement of callose within root CWs inefficiently protected the protoplast from $\mathrm{Pb}$ penetration. As a result,
\end{abstract}

Handling Editor: Bhumi Nath Tripathi

S. Samardakiewicz $(\square)$

Laboratory of Electron and Confocal Microscopy,

Faculty of Biology, Adam Mickiewicz University,

89 Umultowska Street,

61-614 Poznań, Poland

e-mail: sas@amu.edu.pl

M. Krzesłowska • A. Woźny

Laboratory of General Botany, Faculty of Biology,

Adam Mickiewicz University,

89 Umultowska Street,

61-614 Poznań, Poland

H. Bilski $\cdot$ R. Bartosiewicz

Laboratory of Electron Microscopy, Nencki Institute

of Experimental Biology Polish Academy of Sciences,

3 Pasteur Street,

02-093 Warszawa, Poland
$\mathrm{Pb}$ was commonly present inside the root cells. In the light of the results, the barrier role of callose against metal ion penetration appears to be less obvious than previously believed. It was indicated that induction of callose synthesis is not enough for a successful blockade of the stress factor penetration. Furthermore, it would appear that the pattern of callose distribution has an important role in this defence strategy.

Keywords $\mathrm{Pb} \cdot$ Callose $\cdot$ Root $\cdot$ Duckweed $\cdot$ Tolerance $\cdot$ Cell wall

$\begin{array}{ll}\text { Abbreviations } \\ \mathrm{Pb} & \text { Lead ions } \mathrm{Pb}^{2+} \\ \text { callose } & 1,3 \beta \text {-glucan } \\ \text { TEM } & \text { Transmission electron microscopy } \\ \text { IS } & \text { Intercellular spaces } \\ \mathrm{CW} & \text { Cell wall } \\ \mathrm{CWs} & \text { Cell walls }\end{array}$

\section{Introduction}

According to the Environmental Protection Agency, $\mathrm{Pb}$ is one of the most common heavy metal contaminants in the environment (Pattee and Pain 2003). It is a non-essential element in metabolic processes and of critical concern to human and environmental health, because it is a persistent contaminant, has a low solubility, and is classified as carcinogenic and mutagenic (Diels et al. 2002; Prasad 2004). One of the most obvious symptoms of $\mathrm{Pb}$ toxicity in plants is the rapid inhibition of their growth. This has been attributed to several factors, among which is a decrease in 
mitotic activity (Wierzbicka 1999; Samardakiewicz and Woźny 2005; Glińska et al. 2007). Plants have developed various resistance strategies against $\mathrm{Pb}$, which include a range of avoidance mechanisms (Prasad 2004; Vorwerk et al. 2004; Vinocur and Altman 2005), for example formation of physical and/or chemical barriers which partly or completely limit the penetration of the organism by this stress factor. One of the most common strategies which protect plant cells from abiotic as well as biotic stress factors, e.g. infection by fungal pathogens or viruses, is the formation of the callose layer (Epel 2009; Hématy et al. 2009; Luna et al. 2011). Induction of this cell wall (CW) compound synthesis has also been observed under the influence of trace metals such as Al, Cd, Co, Cu, Ni, and Zn (Peterson and Rauser 1979; Llugany et al 1994; Kartusch 2003; Ueki and Citovsky 2005; Poschenrieder et al. 2008; Stass and Horst 2009). The precise role of the induction of callose synthesis in plant cells exposed to toxic metal ions is still unclear. The newly produced callose may, for example, perform the function of a physical barrier which can inhibit the transport of metal ions from the apoplast to the symplast (Eticha et al. 2005; Krzesłowska 2011). However, in roots of Lemna minor exposed to $\mathrm{Pb}$, despite the induction of callose synthesis and its deposition in the root apex (Samardakiewicz et al. 1996), $\mathrm{Pb}$ quickly appeared within the protoplasts (Samardakiewicz and Woźny 2000). Therefore, the present study was undertaken to attempt to explain the cause of this phenomenon.

\section{Material and methods}

Lemna minor L. (duckweed) plants were cultured on a liquid medium according to Wang (1990): $\mathrm{NaNO}_{3}$ (225 mg l $\left.\mathrm{m}^{-1}\right), \mathrm{NaHCO}_{3}\left(150 \mathrm{mg} \mathrm{l} \mathrm{l}^{-1}\right), \mathrm{MgSO}_{4} \cdot 7 \mathrm{H}_{2} \mathrm{O}$ $\left(147 \mathrm{mg} \mathrm{l}^{-1}\right), \mathrm{MgCl}_{2} \cdot 6 \mathrm{H}_{2} \mathrm{O}\left(121.6 \mathrm{mg} \mathrm{l}^{-1}\right), \mathrm{CaCl}_{2} \cdot 2 \mathrm{H}_{2} \mathrm{O}$ (44.1 $\left.\mathrm{mg} \mathrm{l}^{-1}\right), \mathrm{K}_{2} \mathrm{HPO}_{4}\left(10.4 \mathrm{mg} \mathrm{l} \mathrm{l}^{-1}\right), \mathrm{MnCl}_{2} \cdot 4 \mathrm{H}_{2} \mathrm{O}$ (4.15 mg $\left.1^{-1}\right), \quad \mathrm{Na}_{2}$ EDTA $2 \mathrm{H}_{2} \mathrm{O}\left(3 \mathrm{mg} \mathrm{l} \mathrm{l}^{-1}\right), \mathrm{FeCl}_{3}$ $\left(0.96 \mathrm{mg} \mathrm{l}^{-1}\right), \mathrm{H}_{3} \mathrm{BO}_{3}\left(1.85 \mathrm{mg} \mathrm{l} \mathrm{l}^{-1}\right), \mathrm{Na}_{2} \mathrm{MoO}_{4} \cdot 2 \mathrm{H}_{2} \mathrm{O}$ $\left(72.6 \mu \mathrm{g} \mathrm{l}^{-1}\right), \mathrm{ZnCl}_{2}\left(32.7 \mu \mathrm{g} \mathrm{l}^{-1}\right), \mathrm{CoCl}_{2}\left(7.8 \mu \mathrm{g} \mathrm{l}^{-1}\right)$, $\mathrm{CuCl}_{2}\left(0.11 \mu \mathrm{g} \mathrm{l}^{-1}\right)$. The plants, which were to be the object of the study, were obtained from the Prof. E. Landolt collection (Geobotanical Department of ETH, Zürich) and have been cultivated for many years in in vitro conditions in our laboratory. Stock cultures were incubated on Wang medium under a constant illumination of $70 \mu \mathrm{mol} \mathrm{m} \mathrm{s}^{-2}$ at $23 \pm 1^{\circ} \mathrm{C}$. For the experiments, morphologically similar individuals were transferred for $6 \mathrm{~h}$ to a 50 -fold diluted Wang medium with lead nitrate, containing $15 \mu \mathrm{M} \mathrm{Pb}$. After such exposure conditions, $\mathrm{Pb}$ occurred in all layers of the root section. Moreover, what was important for the current experiments, in these conditions the amount of $\mathrm{Pb}$ within $\mathrm{CW}$ was markedly higher (Samardakiewicz and Woźny 2000). In addition, the 6-h plant exposure to $\mathrm{Pb}$ was also the period of time exposure to $\mathrm{Pb}$ for callose induction (Samardakiewicz et al. 1996).

Callose was detected with aniline blue and observations were performed with a fluorescent microscope Axiovert 2000 M (Carl Zeiss, mercury lamp HB200) and in a transmission electron microscopy (TEM) (JEOL JEM 1200 EX II) by using immunogold detection with the anti- $\beta-1,3-$ glucan antibody (Biosupply) according to the method described by Zadworny et al. (2007).

Lead taken up by plants was localized by using the TEM supplied with a scanning attachment and a Link AN 10000 Energy-Dispersive Spectrometry system for X-ray mapping microanalysis of chemical elements (Samardakiewicz and Woźny 2000). This method was also used for co-localization of lead and signals from gold particles, reflecting the location of callose. The observations were performed in the three replications on the basis of approximately a dozen cross sections of nine roots.

\section{Results}

The treatment of $L$. minor $\mathrm{L}$. plants with $\mathrm{Pb}$ for $6 \mathrm{~h}$ resulted in the induction of the synthesis and deposition of callose in their roots. This was not present in the control roots, with the exception of the root cap cells, and rarely detected in such $C W$ regions of $L$. minor roots exposed to this metal where no $\mathrm{Pb}$ occurred (Fig. 1a, b). Thanks to immunodetection of callose in TEM it was possible to show precisely the regions of callose occurrence in plant tissues and within individual cells. Thus, it was revealed that although callose was rather commonly synthesized in roots of $L$. minor treated with $\mathrm{Pb}$, it was not evenly distributed in root tissues and within the cells. Callose was predominantly detected in the protoderm and in the centre of the root tip (procambial central cylinder) (Fig. 1b). This corresponded to the callose distribution detected by means of the fluorescent microscope (Fig. 1b).

Callose was identified in a relatively high amount in the newly formed CW (Fig. 1c, d). It primarily occupied their central parts, sometimes accompanied by irregular CW thickening formation or near the border between the newly formed $\mathrm{CW}$ and the $\mathrm{CW}$ of the mother cell (Fig. 1c, d). Moreover, callose was often observed in the anticlinal CW. In such cases, it was evenly distributed throughout their length and formed rather continuous bands (Fig. 1g). In the other CWs of Lemna roots, e.g. tangential and radial ones, the immunodetection in TEM showed that callose formed only small clusters or broken bands (Fig. 1e, f, h, i). In tangential CWs gold particles, reflecting the location of callose was visible in the outer $\mathrm{CW}$ of the protoderm in the region of the junction of two cells (Fig. 1e, f). In the radial CWs, most of the gold particles identifying callose were 

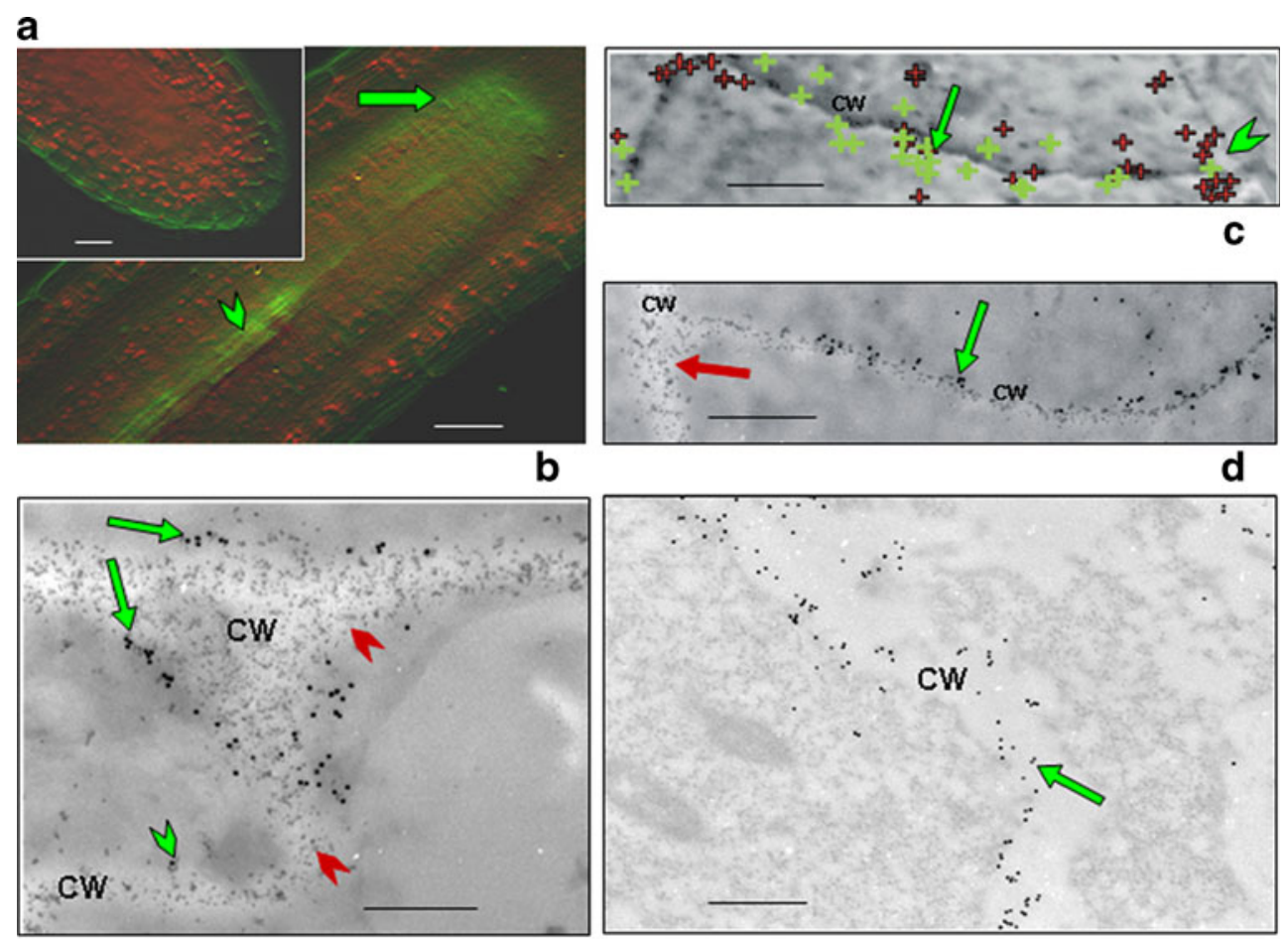

e

h

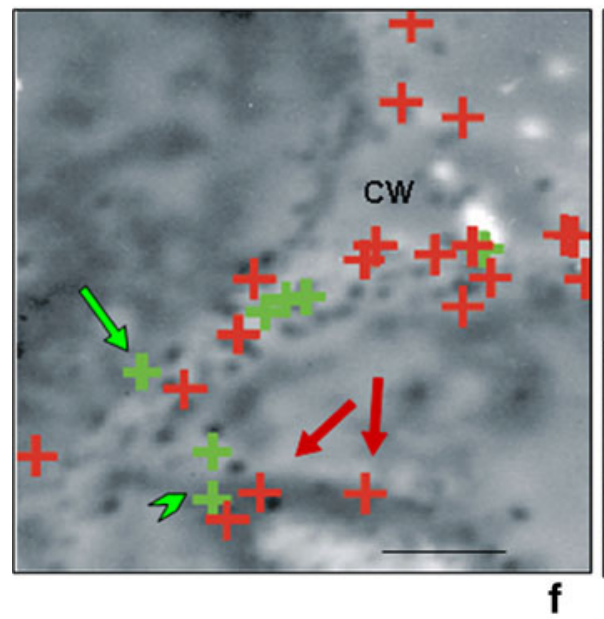

Fig. 1 Occurrence and distribution of lead $(\mathrm{Pb})$ and callose in Lemna minor $\mathrm{L}$. cells of the root tip; $C W$ cell wall; $\mathbf{a}, \mathbf{b}$ detection of callose by aniline blue staining (green colour) and autofluorescence of chlorophyll (red colour). Root cells of $L$. minor contain chloroplasts in the root (like other water plants), even in the root tip. The occurrence of chloroplasts and the absence of proplastids in meristematic cellsunusual for vascular plants (Landolt 1986). a control cells containing callose only in the $\mathrm{CW}$ of the root cap, $\mathbf{b}$ callose in the protoderm (green arrow) and in the procambial central cylinder (green arrowhead) in lead-treated plant. $\mathbf{c}-\mathbf{j}$ Detection of callose and $\mathrm{Pb}$ by TEM in plant exposed to lead, callose indicated by immunogold (black particles), $\mathrm{Pb}$ visible as the electron-dense, greyish deposits, $\mathbf{c}$, f callose and $\mathrm{Pb}$ detected by the X-ray mapping microanalysis (callose-green cross, $\mathrm{Pb}$-red cross), $\mathbf{c}, \mathbf{d}$ callose which forms continuous

localized within the plasmodesmata (Fig. 1j) and sometimes in the local CW thickenings (Fig. 1f, h, i).

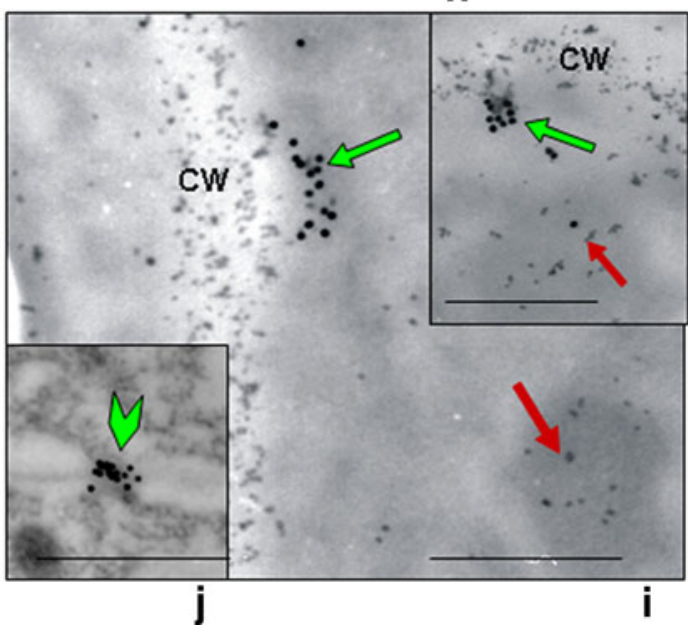

bands localized in newly formed $\mathrm{CW}$ in its central part (green arrow and green cross) and near the border between the newly formed CW and the mother $\mathrm{CW}$ (green arrowhead). $\mathrm{Pb}$ deposits in $\mathrm{CW}$ (red arrow and red cross), e callose visible in the outer tangential $\mathrm{CW}$ of the protoderm (green arrow) and $\mathbf{f}$ in the radial $\mathrm{CW}$ (green arrowhead) as small clusters or incomplete band. $\mathrm{Pb}$ deposits localized mostly in the $\mathrm{CW}$ (red arrowhead), much lower amount of $\mathrm{Pb}$ detected in the protoplast than in the $\mathrm{CW}$ (red arrow), $\mathrm{g}$ callose which forms a continuous band in anticlinal $\mathrm{CW}$ of root tip (green arrow) $-\mathrm{Pb}$ not visible in this case, $\mathbf{h}-\mathbf{j}$ localization and distribution of callose and $\mathrm{Pb}$ in radial CW. Callose indicated in the area of plasmodesmata (green arrowhead) and in the $\mathrm{CW}$ thickening (green arrow), $\mathrm{Pb}$ localized mostly in the $\mathrm{CW}$, much lower amount of $\mathrm{Pb}$ in the protoplast than in the CW (red arrow), a, b Bars $25 \mu \mathrm{m}, \mathbf{c}-\mathbf{j}$ Bars $200 \mathrm{~nm}$

It was indicated that root meristem of Lemna, in contrast to root meristems of land plants, contained evenly spaced 
intercellular spaces (IS). In the CWs adjacent to those IS, small clusters of gold particles reflecting the location of callose were also detected.

Distribution of callose in Lemna CWs only partly corresponded to $\mathrm{Pb}$ localization. $\mathrm{Pb}$ deposits were commonly observed within the protoplasts (Fig. 1f, h, i). However, using TEM X-ray microanalysis, we showed that in newly formed $\mathrm{CW}$ and in the anticlinal $\mathrm{CW}$, where callose often formed continuous bands, a lower number of $\mathrm{Pb}$ signals were detected or $\mathrm{Pb}$ was completely absent (Fig. 1c, d, g). Contrary to this, in the lateral parts of the newly formed $\mathrm{CW}$, where lower number of callose signals were detected, higher number of $\mathrm{Pb}$ signals occurred (Fig. 1c). Thus, the presence of callose in the newly formed $\mathrm{CW}$ limited the amount of $\mathrm{Pb}$ in those $\mathrm{CWs}$ and protoplasts nearby, while in the other CWs, where callose occupied only small $\mathrm{CW}$ regions (Fig. 1f, h, i), Pb deposits occurred in high amounts and only rarely were surrounded by callose clusters (Fig. 1h, i).

\section{Discussion}

Callose may function as a mechanical barrier (Skou 1982; Maor and Shirasu 2005; Krzesłowska 2011) and protect the plasma membrane from metal ion penetration (Cumming and Taylor 1990). Moreover, this polysaccharide, located in the adjacent $\mathrm{CW}$, could also effectively block symplastic transport of metal ions through plasmodesmata (Sivaguru et al. 2000; Levy et al. 2007; Zavaliev et al. 2011). It may protect the plant from a wide spread of toxic metal ions.

However, in the light of the results included in this paper, the barrier role of callose against the penetration of metal ions is not as obvious as previously believed. The obtained results showed that $\mathrm{Pb}$ commonly induced callose synthesis in L. minor roots. When callose formed continuous bands as, e.g. in the newly formed $\mathrm{CW}$ and in the anticlinal $\mathrm{CW}$, then it formed an efficient blockade to prevent $\mathrm{Pb}$ entering the protoplasts. However, in the other CWs of $L$. minor roots, where callose was deposited locally as small clusters or incomplete bands, $\mathrm{Pb}$ was frequently observed within the protoplasts. These facts strongly suggest that the barrier role of callose against $\mathrm{Pb}$ penetration depends on its deposition pattern in the cell.

The induction of callose synthesis has also been observed in other plant species exposed to this metal, e.g. Arabidopsis thaliana (Lummerzheim et al. 1995) or Funaria hygrometrica (Krzesłowska et al. 2009; Krzesłowska et al. 2010). In F. hygrometrica protonema for example, which elongates thanks to the tip-growing apical cell, rich in callose CW thickenings were formed at the cell apex (Krzesłowska and Woźny 2000; Krzesłowska et al. 2009; Krzesłowska et al. 2010). This was the main region where $\mathrm{Pb}$ entered the protonema cell (Krzesłowska and Woźny 1996). Deposited in this site, callose could effectively limit the amount of $\mathrm{Pb}$ entering the protoplast. In fact, a slight amount of $\mathrm{Pb}$ was detected within the protoplast (Krzesłowska and Woźny 2000; Krzesłowska et al. 2009; Krzesłowska et al. 2010). Moreover, it has been shown recently that after transferring the protonemata from the medium containing $\mathrm{Pb}$ to the medium lacking this metal, all $\mathrm{Pb}$ deposits removed from the protoplast to $\mathrm{CW}$ and sequestered there were separated from the protoplast by a callose layer. It undoubtedly protected the cell from $\mathrm{Pb}$ returning to the protoplast. Indeed, almost no $\mathrm{Pb}$ was detected within the protoplast of the transferred protonemata, excluding $\mathrm{Pb}$ accumulated in the vacuole (Krzesłowska et al. 2010). Thus, in F. hygrometrica, callose played an important role in the defence response of the protonemata cell to this metal as an effective barrier markedly limiting the amount of $\mathrm{Pb}$ which entered the protoplasts.

The above appears to show that the effectiveness of callose as a barrier for $\mathrm{Pb}$ penetration might be different in different plants. In $L$. minor roots, unlike those of $F$. hygometrica, although callose synthesis was commonly induced by $\mathrm{Pb}$, its local distribution in most of the $\mathrm{CW}$ did not result in the formation of an efficient barrier against $\mathrm{Pb}$ penetration into the protoplasts.

Hence, it is not a rule that the appearance of callose always effectively protects the plant symplast from the entrance of $\mathrm{Pb}$. It depends markedly on its deposition pattern. To our knowledge, this is the first report of an insufficient barrier being formed by callose in response to $\mathrm{Pb}$, and this may shed a new light on this defence strategy, which can play such a different role in various plants despite being a reaction to the same stress factor.

Acknowledgements This work was supported by grant PBZ KBN110/PO4/2004.

Conflict of interest The authors declare that they have no conflict of interest.

Open Access This article is distributed under the terms of the Creative Commons Attribution Noncommercial License which permits any noncommercial use, distribution, and reproduction in any medium, provided the original author(s) and source are credited.

\section{References}

Cumming JR, Taylor GJ (1990) Mechanism of metal tolerance in plants: physiological adaptations for exclusion of metal ions from the cytoplasm. In: Alscher RG, Cumming JR (eds) Stress response in plants: adaptation and acclimation mechanism. Wiley-Liss, New York, pp 329-356

Diels L, Van der Lelie N, Bastiaens L (2002) New developments in treatment of heavy-metal contaminated soils. Rev Environ Sci Biotechnol 1:75-82 
Epel BL (2009) Plant viruses spread by diffusion on ER-associated movement-protein-rafts through plasmodesmata gated by viral induced host $\beta$-1,3-glucanases. Semin Cell Dev Biol 20:1074-1081

Eticha D, Stass DA, Horst JW (2005) Cell-wall pectin and its degree of methylation in the maize root-apex: significance for genotypic differences in aluminium resistance. Plant Cell Environ 28:1410 1420

Glińska S, Bartczak M, Oleksiak S, Wolska A, Gabara B, Posmyk M, Janas K (2007) Effects of anthocyanin-rich extract from red cabbage leaves on meristematic cells of Allium cepa L. roots treated with heavy metals. Ecotoxicol Environ Saf 68:343-350

Hématy K, Cherk C, Somerville S (2009) Host-patogen warfare at the plant cell wall. Curr Opin Plant Biol 12:406-413

Kartusch R (2003) On the mechanism of callose synthesis induction by metal ions in onion epidermal cells. Protoplasma 220:219-225

Krzesłowska M (2011) The cell wall in plant cell response to trace metals: polysaccharide remodeling and its role in defense strategy. Acta Physiol Plant 33:35-51

Krzesłowska M, Lenartowska M, Mellerowicz EJ, Samardakiewicz S, Woźny A (2009) Pectinous cell wall thickenings formation- a response of moss protonemata cells to lead. Environ Exp Bot 65:119-131

Krzesłowska M, Lenartowska M, Samardakiewicz S, Bilsk H, Woźny A (2010) Lead deposited in the cell wall of Funaria hygrometrica protonemata is not stable - a remobilization can occur. Environ Pollut 158:325-338

Krzesłowska M, Woźny A (1996) Pb uptake localization and changes in cell ultrastructure of Funaria hygrometrica protonemata. Biol Plantarum 38:253-259

Krzesłowska M, Woźny A (2000) Wall thickenings - moss protonemata apical cell reaction to $\mathrm{Pb}$. Biol Plantarum 43:93-98

Landolt E (1986) The family of Lemnaceae — a monographic study. Ver Geobot Inst ETH, Stiftung Rübel, Zürich

Levy A, Guenoune-Gelbart D, Epel B (2007) b-1,3-Glucanases: plasmodesmal gate keepers for intercellular communication. Plant Signal Behav 2:404-407

Llugany M, Massot N, Wissemeier AH, Poschenrieder C, Horst WJ, Barceló J (1994) Aluminum tolerance of maize cultivars as assessed by callose production and root elongation. Z Pflanzenernahr Bodenkd 157:447-451

Lummerzheim M, Sandroni M, Castresana C, De Oliveira D, Van Montagu M, Roby D, Timmerman B (1995) Comparative microscopic and enzymatic characterization of the leaf necrosis induced in Arabidopsis thaliana by lead nitrate and by Xanthomonas campestris pv. Campestris after foliar spray. Plant Cell Environ 18:499-509

Luna E, Pastor V, Robert J, Flors V, Mauch-Mani B, Ton J (2011) Callose deposition: a multifaceted plant defense response. Mol Plant Microbe Interact 24:183-193

Maor R, Shirasu K (2005) The arms race continues: battle strategies between plants and fungal pathogens. Curr Opin Microbiol $8: 399-404$
Pattee OH, Pain DJ (2003) Lead in the environment. In: Hoffman DJ, Rattner BA, Burton GA, Cairns JDJ, Hoffman BA, Rattner GA, Burton JC (eds) Handbook of ecotoxicology, 2nd edn. Lewis Publishers, CRC Press LLC, Boco Raton, Florida, pp 373-408

Peterson CA, Rauser WE (1979) Callose deposition and photoassimilate export in Phaseolus vulgaris exposed to excess cobalt, nickel and zinc. Plant Physiol 63:1170-1174

Poschenrieder C, Gunse B, Corrales I, Barcelo J (2008) A glance into aluminium toxicity and resistance in plants. Sci Total Environ 400:356-368

Prasad MNV (2004) Heavy metal stress in plant: from molecules to ecosystems. Springer, Heidelberg

Samardakiewicz S, Strawiński P, Woźny A (1996) The influence of lead on callose formation in roots of Lemna minor L. Biol Plantarum 38:463-467

Samardakiewicz S, Woźny A (2000) The distribution of lead in duckweed (Lemna minor L.) root tip. Plant Soil 226:107-111

Samardakiewicz S, Woźny A (2005) Cell division in Lemna minor roots treated with lead. Aquat Bot 83:289-295

Sivaguru M, Fujiwara T, Šamaj J, Baluška F, Yang ZM, Osawa H, Maeda T, Mori T, Volkmann D, Matsumoto H (2000) Aluminum-induced $1 \rightarrow 3$ - $\beta$-d-glucan inhibits cell-to-cell trafficking of molecules through plasmodesmata. A new mechanism of aluminum toxicity in plants. Plant Physiol 124:991-1005

Skou JP (1982) Callose formation responsible for the powdery mildew resistance in barley with genes in the $m l-o$ locus. Phytopathol Z 104:90-95

Stass A, Horst WJ (2009) Callose in abiotic stress. In: Bacic A, Fincher GB, Stone BA (eds) Chemistry, biochemistry and biology of $(1 \rightarrow 3)-\beta$-glucans and related polysaccharides. Academic, New York, pp 499-524

Ueki S, Citovsky V (2005) Identification of an interactor of cadmium ion-induced glycine-rich protein involved in regulation of callose levels in plant vasculature. Proc Natl Acad Sci U S A 102:12089-12094

Vinocur B, Altman A (2005) Recent advances in engineering plant tolerance to abiotic stress: achievements and limitations. Curr Opin Biotechnol 16:123-132

Vorwerk S, Somerville S, Somerville C (2004) The role of plant cell wall polysaccharide composition in disease resistance. Trends Plant Sci 9:203-209

Wang W (1990) Literature review on duckweed toxicity testing. Environ Res 52:7-22

Wierzbicka M (1999) The effect of lead on the cell cycle in the root meristem of Allium cepa L. Protoplasma 207:186-194

Zadworny M, Smoliński DJ, Idzikowska K, Werner A (2007) Ultrastructural and cytochemical aspects of the interaction between the ectomycorrhizal fungus Laccaria laccata and the saprotrophic fungi, Trichoderma harzianum and T-virens. Biocontrol Sci Technol 17:921-932

Zavaliev R, Ueki S, Epel BL, Citovsky V (2011) Biology of callose ( $\beta$ 1,3-glucan) turnover at plasmodesmata. Protoplasma 248:117-130 